\title{
Voksenutdannelse, folkeopplysning og demokrati. Aktuelle og omfangsrike antologier
}

\section{Av Olav Klonteig}

Ove Korsgaard, Bo Vestergård Madsen og Niels Kayser Nielsen (red.), Idraet, krop og demokrati (Gads Forlag, København, 2001), 253 s.

Ove Korsgaard (red.), Poetisk demokrati (Gads Forlag, København, 2001), 273 s.

Jørgen Gleerup (red.), Voksenuddannelse under forandring (Gads Forlag, København, 2001), 282 s.

Lotte Rahbæk Schou (red.), Demokrati og livslang laering, (Gads Forlag, København, 2001), 192 s.

De fire bøker er produkt av et forskningsprosjekt som undersøker forholdet mellom voksenutdannelse, folkeopplysning og demokrati i lys av de forandringer som preger det danske samfunn i vår tid. Arbeidet er gjennomført av Forskningscenter for Voksenuddannelse og Danmarks Pædagogiske Universitet i samvirke med Center For Kulturstudier og Syddansk Universitet. Lektor ved DPU, Ove Korsgaard, har vært prosjektleder.

Antologien har 36 skribenter, de fleste danske pluss to svenske, to fra Syd-Afrika og to fra USA. Her er 50 artikler/essays på i alt 1000 sider.

Både tiltaket og gjennomføringen av det må sies å være rosverdig. De mange innfallsvinkler gir oss rikelig med lyskastere over temaet. Men selve stoffmassen kan nok virke noe uhåndterlig for leseren, og det er ikke alle artiklene som går like lett inn i sammenhengen. At strukturen dermed blir noe løs, er vel noe man må ta med på kjøpet i denne typen av antologier. Noen sentrale termer, så som 'livslang læring', 'folkeopplysning', 'kompetanse', 'globalisering' kunne vel ha fătt en nærmere begrepsavklaring tidlig i serien. Dette er synspunkt som lettere dukker opp i bakspeilet enn i planlegningen.

Det er ikke en avhandling vi har for oss. Derfor vil denne omtalen være mer en presentasjon enn en vurdering.

Vi vil først gi en kort oversikt over innholdet i de fire bøkene. Dernest følger vi et par av de sentrale temaer.

Idrcet, krop og demokrati

Her møter vi skiftende tiders oppfatninger av hvordan ulike former for 
kroppsaktivitet gjenspeiler og står til tjeneste for idéstrømninger i samfunnet, med disiplinering og frigjøring som ytterpunkter. Sport og idrett har en oppdragende funksjon. Vi ser også kroppen som symbol, legemliggjøring av rådende ideer i tiden, kroppen som inkarnasjon og representasjon. Der til eksempel sporten uttrykker den individuelle kraftprestasjon (liberalismen), mens den folkelige gymnastikk markerer det sosiale fellesskap (demokratiet). Ut fra mange synsvinkler blir det således kastet lys over det betydningsbærende ved kroppsaktiviteter.

For højskolehistorien vil det ha særlig interesse å møte 1930-årenes kontraster i kroppskulturen. Klara Aalbæk Korsgaard skriver:

Ved gymnastikopvisninger var tilskuerne allerede ved indmarchen ikke i tvivl om et hold kom fra Ollerup Gymnastikhøjskole eller Snoghøj, for Snoghøjs piger nærmest svævede hen over græsset.

\section{Poetisk demokrati}

Original kobling! Utfordringene i dag synes å kreve ny tenkning over de ideer vi har forbundet med demokratiet. Hvis for eksempel begrep som 'folk' og 'nasjon' har tapt sin tradisjonelle kontekst, er vi tvunget til å tenke radikalt nytt, til å utvikle en skapende, kreativ, det vil si en poetisk holdning. Både individ og samfunn er kastet ut i usikkerhet. De enkelte fenomen er kanskje ikke nye, men summen av dem og forandringstakten er $\varnothing$ kende. Hva innebærer det at både den enkelte og samfunnet må $\emptyset$ ve seg i en ny rolle, må reflektere over seg selv og organisere seg selv?

Det gamle problem med å bygge bro mellom individ og samfunn har fått ny aktualitet og blir drøftet i lys av våre dagers vilkår. Sentralt står temaet om demokratiet som styreform og som livsform. Her møter vi selvsagt Grundtvig (Regner Birkelunds artikkel). Grundtvig kan delta i vår tids brobygging mellom individ og samfunn, fordi for ham var veien til det gode liv grunnleggende den samme som veien til det gode samfunn.

Det er stort sett god sammenheng mellom artiklene. Det standpunkt at medborgerskap ikke kan baseres på felles kultur og væremåter, men må ta utgangspunkt i politiske rettigheter og demokratiske verdier, der individualitet og fellesskap gjensidig styrker hverandre, kan vi følge både hos Koch, Durkheim og Habermas.

I sluttfasen står den moderne selvdannelse $\mathrm{i}$ fokus. Vi får tilført tankegods fra en rekke filosofer: Høffding, Bukdahl, Bruner, Foucault, Rorty, Derrida, Arendt og Dewey. 


\section{Voksenuddannelse under forandring}

Her blir våre dagers utdannelsespolitikk og flere grener innenfor voksenundervisningen nærmere belyst, blant annet Aftenskolen, AMU, VUC.

"Der er kommet opbrud i uddannelsesdiskursene", sier Jørgen Gleerup. Innenfor VUC er en fornyelse i gang, der isolert formidling av teoretisk viten viker plassen for en mer allsidig 'kompetanseutvikling'. Det betyr mer tverrfaglig, erfaringsbasert, konkret, praktisk anvendbar og sosial læring. Dette skjer via et nettverk av flere samarbeidspartnere. Dels kan utdannelsen da komme nærmere arbeidslivets behov. Dels kan den åpne for mer demokratiske læreprosesser.

Vi hører den nye $\emptyset$ konomismens inntogsmarsj, der markedsstyringen overtar etter verdistyringen. Evalueringsbølgen er ett av de nye trekk. Peter Dahler-Larsen påviser hvordan evaluering ikke kun er en nøytral beskrivelse, men at den også påvirker det som blir evaluert. Særlig er det fare for at verdibaserte aktiviteter, knyttet til dannelse og folkeopplysning, blir underbelyst, fordi evalueringen avgrenser seg til det som er snevert nyttig og målbart.

Vi får en spennende sammenligning mellom svensk og dansk folkehøgskole.

Til slutt blir situasjonen for 'restgruppen' og det multietniske samfunn drøftet i lys av hovedtemaet.

\section{Demokrati og livslang laering}

Her får vi en grundigere drøftelse av antologiens temaer - innover mot demokratiske læreprosesser, utover mot globaliseringen. Artiklene har ganske forskjellige innfallsvinkler. Vi møter igjen spenningsfeltet mellom den humanistiske, identitetsorienterte opplysning på den ene side og den utdannelsespolitiske, økonomi- og markedsorienterte hensikt med 'livslang læring' på den andre side.

Lotte Rahbek Schou hevder at når utdannelsen blir produktivkraft for $\emptyset$ konomien, står vi i fare for å få et instrumentelt forkortet undervisningsbegrep, der dannelsestradisjonen faller ut. "Oppgaven fremover", sier Henrik Kaare Nielsen, "må være å arbeide for at arbeidsmarkedets behov blir integrert $\mathrm{i}$, men underordnet et dannende og demokratifremmende sikte."

Finn Thorbjørn Hansen presenterer selvdannelse og eksistensiell pedagogikk som et nødvendig motspill til det markedsorienterte, som begrepet 'livslang læring' i dag er dominert av. 
Sentrale spørsmål blir om demokratiet kan fungere hvis læringen ikke har et myndiggjørende og etisk verdibasert grunnlag? Den moderne 'selvdannelse' - hvordan kan den løfte seg fra det selvsentrerte og bli betydningsbærende - både eksistensielt og i retning av medborgerskap i demokratiet?

\section{Noen linjer gjennom antologien}

Det vil ikke være mulig i denne omtalen å gi et helhetlig bilde av de fire bøkene. Her vil vi avgrense oss til å ta frem noen av de linjer som kan trekkes gjennom antologien.

\section{Demokrati som livsform og samfunnsform}

En av linjene vil berøre højskolens historie og aktuelle utfordring. I Poetisk demokrati har Regner Birkelund artikkelen 'Grundtvig og demokratiet - om oplysning, dannelse og demokrati'. Vi møter straks både det originale og det radikale hos Grundtvig. Hans folkestyre-begrep er både dypere og bredere enn slik 'demokrati' ofte blir brukt. Som kjent gjelder hans engasjement ikke form, men innhold, ikke juridiske styringsregler, men samfunnsutviklingen i det hele. Grundtvig ville "en splinterny Tilstand af det Borgerlige Selskab, hvori de utabelige MenneskeRettigheder virkelig gøres giældende" (Danskeren 1848, 174). I dag har vi en ny debatt om menneskerettigheter som grunnlag for et globalt, demokratisk nettverk.

Birkelund understreker at det globale perspektivet hos Grundtvig er en del av hans ontologiske utgangspunkt. Det hører til menneskets vesen som Gud-skapt at det har et etisk potensiale, muligheter for det gode liv. I vår evne til barmhjertighet og vår harme over urettferdighet ligger etiske normer for vårt samfunnsliv. Det er dette felles trekk hos mennesker som opplysning og dannelse skal fremelske og utvikle. Det sentrale for Grundtvigs folkestyre-tanker blir da ideen om samfunnet som et etisk fundert fellesskap. Livsopplysning er derfor ikke tilførsel utenfra av abstrakt viten om livet, men en vekstprosess som utvider forståelsen for tilværelsens dimensjoner. Erfaringer fra nærhetsområdene, fra det levde liv, går forut for teorier om det.

Birkelund lar 'det nasjonale' sammenfalle med 'det folkelige' hos Grundtvig. Men i den historiske kontekst, der Grundtvigs avstand til de nasjonal-liberale hører med, vil jeg mene at 'det folkelige' er det sentrale hos Grundtvig. Her vil da 'folkelig opplysning' stå for den opplysning 
som er selvstyrende, båret av bevegelser i sivilsamfunnet, til forskjell fra 'folkeopplysning', som er mer omfattende, der det offentliges ansvar for å opplyse folket også er med. Det folkelige forstår jeg som menneskets nødvendige vekstvilkår, den jord individet modnes $\mathrm{i}$, en modning som bygger bro til den universale dimensjon. Dermed blir det folkelige et vern både mot individualisme og nasjonalisme, noe som også Birkelund markerer.

Går vi herfra til Niels Buur Hansens artikkel i Voksenuddannelse under forandring, møter vi højskolen slik den utfoldet seg i praksis.

Sterkere påvirket av Kold enn av Grundtvig ble den selvstendige gårdmannsfamiliens og menighetens livsform modeller for højskolens organisasjon og også for dens samfunnsforståelse. (Jeg ser det slik at Kold forsterket visse elementer hos Grundtvig og så bort fra andre.)

Disse modellene var nærmest apolitiske. Vekten ble ikke lagt på politikk (hva vi vil), men på identitet (hvem vi er). Buur Hansen hevder at "de grundtvigske folkehøjskoler aldrig har taget demokratiet til sig som en afgørende del av deres oplysningsgrundlag" (s. 140). For Kold ble begrepet 'samfunn' det som oppstår når individet identifiserer seg med sin hjemlige, danske kultur og med sin Gud. Dermed blir højskolens tradisjon koblet til den forståelse av 'folk' som Ove Korsgaard kaller "folk som ethnos", ikke "folk som demos" (Korsgaards artikkel i Poetisk demokrati).

I tiden 1850-1900 blir denne livsformens selvstendighet sterkt utviklet, langs to spor: dels den nevnte etnisk-kulturelle åndsretning, dels ved at sivilsamfunnet utstyrer seg selv med et alternativt marked (andelsbevegelsen). Dermed blir 'samfunnet' utskilt fra 'staten'. Samfunnet blir det som gror innenfra, det naturlige, det privatbaserte, fellesskapet mellom de som deler den samme kulturarv, det samme språk, den samme mentalitet. Staten, derimot, blir noe 'der ute', noe kunstig, formelt, som utenfra vil gripe inn og regulere. I denne sammenheng ses demokratiets oppgave avgrenset til å verne om blant annet folkets rett til selv å stå for en holdningsbasert opplysning.

Nettopp fordi denne tradisjonelle livsform så sterkt kom til å prege højskolens selvforståelse, blir den problematisk når samfunnet forandrer seg. Hansen konkluderer med at højskolen i dag utfordres til å utvide sin identitetsdiskurs med en politisk diskurs.

Mitt inntrykk er at hvis man presser ensidig på den første diskurs, avskjærer man seg også fra Grundtvigs brobygging fra det folkelige til det universelle.

Den som klarest står for den politiske diskurs som Buur Hansen 
etterlyser, er Hal Koch. Ove Korsgaard skriver om ham i Poetisk demokrati.

Nazitiden vekker bevisstheten om de demokratiske verdiene, og Koch hevder at det er ikke i det kulturelle, men i det politiske vi finner det som binder oss sammen. Kulturene er vokset frem lokalt, og de er forskjellige fra sted til sted. Demokratiet, derimot, bygger på den kjerne av humanitet som er i alle mennesker.

Nå sier Koch også at demokrati er en "livsform". Her er det viktig å avklare, slik Korsgaard gjør, at Koch legger noe annet i 'livsform' enn det vi brukte i omtalen av landmannskulturen, og det ligger langt fra det man nå kaller 'livsstil'. 'Livsform' hos Koch er ikke hverdagens skikk og bruk eller tilvant væremåte. Det er en mer opplyst tankeform, som har sine røtter i den europeiske, humanistiske tradisjon, i det gresk-kristne arvegods.

Vi blir ikke født som samfunnsborgere. Derfor blir folkeopplysning en forutsetning for demokratiet. Toleranse i verdslige spørgsmål langmodighet, evne til å møtes på halvveien - er borgerdyder som vi må oppdrages og opplæres i. Opplysningens formål er da å myndiggjøre, demokratisere borgerne. Demokratiet må oppøves som livsform før det kan fungere som samfunnsform.

Man kan vel si at skal det liberale frihetsbegrep bli demokratisk, må det avbalanseres av likhetsbegrepet. Solidaritet med de svake og utjevning av økonomisk ulikhet blir viktig. Derved blir de etiske normer, livets grunnlover, et sentralt utgangspunkt for det politiske.

Rykker vi så frem til vår egen tid, kan man ikke si at vilkårene for å bygge bro fra individuell til demokratisk utvikling er særlig lyse. Elevenes valgfrihet har slått igjennom på højskolene, og når de ikke er interessert i politikk, blir det lite undervisning i samfunnstemaer. Man taler om at "højskole-Venstre" er redusert til "handelshøjskole-Venstre". Tiltak med røtter i det folkelige Danmark er fjernet, andre er under sterkt press (Daghøjskolene og Efterskolene).

Hovedakt $\varnothing r$ i utviklingen er selvsagt 'markedsgjøringen'. Globaliseringen domineres av markedet, og markedet har nyliberalismen som politisk ideologi. Når vekten legges på materielle verdier, blir de immaterielle verdier skjøvet i bakgrunnen. Flere av antologiens forfattere er kritiske til denne utvikling. Men jeg savner en sammenhengende analyse av hva konsekvensene kan bli av at all utdannelse blir definert som produksjonsfaktor. Humanismen har jo en annen referanseramme enn humankapitalismen. Blant annet er den viten som skaper varer noe annet enn den viten som skaper betydning for mennesker. 
Man kan håpe på at dansk skolekultur og dens utøvere har styrke til å stå imot de økonomiske vinder som blåser fra Finansministeriet.

\section{Narrativ kompetanse og eksistensiell selvdannelse}

Mange av artiklene fornyer lyssettingen på deler av det pedagogiske arvegodset eller de drøfter nye utdannelsesbegreper - 'livslang læring', 'medborgerskap', 'selvdannelse'.

Kolds fortelling gjenoppstår i ny skikkelse i Marianne Horsdals 'Narrativ metode'. Den nye 'selvdannelse' blir diskutert i Finn Thorbjørn Hansens 'Selvdannelse og eksistensiell voksenpædagogik' (Begge i Demokrati og livslang loering).

Jeg stanser ved disse artiklene. Ser vi tilbake på Grundtvig og Løgstrup, tenkte de ut fra en klar visshet om at tilværelsen er full av mening og betydning. Men vår tids økonomisme og postmodernisme har ingen slik mening å tilby, og det er fare for at 'videnssamfundet' kan skape en ny almue. "Risikosamfunnet' kan bli 'det søkende samfunn". Meningsfylde må gjenfinnes eller skapes på nytt. Horsdals og Hansens artikler går inn i denne sammenhengen.

\section{Fortellingens betydning}

Fra barnsben av konstruerer vi sammenheng ved selv å fortelle og å høre andre fortelle fra sine liv. Slik lærer vi oss selv å kjenne og slik føres vi inn i andres erfaring og opplevelser. Historier er stedfortredende erfaring, sier Horsdal, og de innfører oss i den kulturelle sammenheng.

I vår tid, preget av fragmenter, sterk mobilitet og oppsplitting, er det fare for at vi taper oss selv. Derfor trenger vi å bli bevisste om vår egen livshistorie, fordi det er sammenheng som gir mening som gir livsfylde. Den ekte, personlige samtale styrker deltakerens identitet, samtidig som ens forståelse for det som er annerledes, utvides.

Dette temaet får forsterket betydning i Horsdals artikkel 'Kulturmøde og medborgerskab' i Voksenuddannelse under forandring. I tillegg til livshistorier fra 120 danskere har hun slike fortellinger fra ca. 30 innvandrere. Hun understreker at man kan ikke forvente ansvarlighet overfor et sosialt fellesskap hvis man ikke har adgang til det. Noen unge innvandrere deltar i fellesskaper mot samfunnet. De mangler styrke til å finne en sammenheng i deres liv. Andre kan utvikle en nostalgisk etnisk identitet som en skjerm mot de kolde danske holdninger. Men mange er underveis til å bli handlende subjekter i deres eget liv. I denne situasjonen er det helt vesentlig at vi får bygget opp en narrativ kompetanse. Vi må 
møtes om våre fortellinger, skape mange dialogiske rom $\mathrm{i}$ voksenutdannelsen, slik at 'oss og dem' kan avløses av et 'vi'.

Jo mer differensiert samfunnet blir, jo sterkere blir tendensen til at vi generaliserer i møtet med andre mennesker. Vi tenker i funksjoner, ikke i hele personer. Dermed øker fordommene. Først når vi får en historie, blir vårt liv en levende sammenheng. "Narrative kompetencer kan udvikle vores respekt for menneskelig værdighed og vores evne til at betragte forskelle som en berigelse" (s. 282).

\section{Eksistensiell opplysning}

Finn Thorbjørn Hansen har i en årrekke forsket i eksistensiell voksenpedagogikk. Særlig gjennom sin presentasjon av "en sokratiske dialoggruppe" har han vært primus motor for rådgivning i verdiavklaring, først for daghøjskolene, dernest for de frie kostskoler. (Vardiafklaring og selvevaluering på de frie kostskoler. DPU, 2001).

Hos Hansen er også samtalen sentral. Men her som en systematisk, reflekterende dialog, en metode til selvdannelse som avklaring av de verdier som deltagerne eller læringsstedet bygger på.

Skal 'livslang læring' virkelig bli selvstyrt, sier Hansen, må den ha en verdibasert kurs å styre etter. Da strekker erfaringspedagogikken ikke til. Den kan være god nok for å nå spesielle læringsmål, som er målrettet og arbeidslivsorientert. Men den er psykologisk og pragmatisk, mangler dybde, etisk og kritisk refleksjon. Skal læringen være dannende, må den bryte hverdagsbevisstheten og stille normative spørsmål: Hvilke verdier vil jeg at mitt liv skal bygge på? Dialogens mål er så å skape større overensstemmelse mellom livsform og livssyn.

Våre handlinger blir bygget opp gjennom meningsskjemaer, dels ut fra våre individuelle livshistorier, dels ut fra normer i vårt kulturmiljø. Ved å bli mer klar over det mønster vi tenker og handler ut fra, og ved å møte andre kulturer, oppdager vi kontingensen - at alt kunne være annerledes. Det åpner for alternativer og utvikler en kritisk refleksjon. Slik kan våre fremtidige valg bli mer selvstyrte. Først da kan vi tale om 'selvdannelse'.

Det er Hansens tese at når vi grunnleggende spør til livets mening, foretar vi et kvalitativt spring inn i en ny refleksjonsform - den kontemplative, den praktisk-poetiske filosoferen. Det er denne Hansen kaller "den eksistensielle dannelse".

Her søker vi ut over grensene for den kritiske fornuft. Vi åpner vårt sinn og lytter til den meningsfylde og "stemthet" som ligger i den unikke livsform vi står i - "den uudsigelige værensfornemmelse." Erkjennelsen 
utvider seg til en stille, ordløs undring, en sinnstilstand som kan oppstå i møte med natur, kunst og andre mennesker.

Opplevelsen er ikke 'nyttig', gir ikke handlingskompetanse eller ferdigheter. Den har egenverdi, hviler i seg selv, har med kjærlighet å gjøre - den gir meningsfylde.

Eksistensiell dannelse er mer enn opplevelsespedagogikk. Opplevelsen skal kombineres med sokratisk tenkning, med sikte på å stadig forbedre sammenhengen mellom konkret liv og livssyn. Den svarer heller ikke til Løgstrups "tilværelsesoplysning”. Man gjør en dyd av å ikke navngi det navnløse. Den er ikke terapi, men vil utdype selvforståelsen, føre deltagerne inn i nye, idemessige landskaper utenfor seg selv - ikke til de områder som kan beskrives som problemer, men til der vi opplever livet som et mysterium.

Hansen håper at denne eksistensielle voksenpedagogikk kan komme sterkere inn i Danmarks og EU's programmer for 'livslang læring', som et fruktbart motspill til den arbeidsmarkeds- og kompetanseorienterte tilgang som råder $\mathrm{i}$ dag.

Med Hansens livsfilosofiske innfallsvinkel er vi kommet til de dypere lag i begrepet 'dannelse'. Han følger stier som nok er ukjente for mange innenfor vanlig voksenundervisning. Men det er vesentlig at denne dimensjonen er med, så det pedagogiske feltet ikke taper takhøyde.

\section{Fra harmoni til konflikt, fra humanisme til humankapitalisme?}

Vi kan vel si at undervisningsfeltet er preget av to forskjellige diskurser en indre pedagogisk og en ytre politisk. Skolen har sitt eget rom, men er også et delsystem i det større samfunnssystem. I det egne rommet har vi samspillet mellom skiftende teorier i forskningen (fagpedagogene) og praktikerne (lærerne) om det som skjer i skolens hverdag. Som delsystem får skolen sitt oppdrag fra politikerne. Det gjelder overordnet formål og sentrale læreplaner. Det gjelder også disiplinering og sortering av elevene, ikke minst skal skolen fordele ungdommen til de forskjellige båser $\mathrm{i}$ arbeidslivet.

Skolen som læringsrom peker i retning av skolen for livet og samfunnet som et sosialt fellesskap og er derfor nært knyttet til livsverdenen. Skolens funksjon som del av samfunnssystemet peker i retning av skolen for arbeidslivet. Den skal tjene bedriften og forretningen Danmark.

Tidligere var forholdet mellom de to diskurser stort sett preget av harmoni, fordi det $\varnothing$ konomiske felt og det pedagogiske felt var autonome 
og adskilte sektorer, som hver ble styrt av sine egne normer, sin egen rasjonalitet.

Fra ca. 1980 skjer det noe radikalt nytt i dette bildet: Den $\varnothing$ konomiske sektor begynner å erobre eller kolonisere den pedagogiske sektor. Vi ser tendensen $\mathrm{i}$ hele den $\mathrm{h} \varnothing \mathrm{y}$-industrialiserte og høy-teknologiske del av verden. Bakgrunnen finnes i markedets iboende ekspansjonstrang. I markedslogikken er manglende ekspansjon lik med stagnasjon. Problemet blir hvordan kan man ekspandere når markedet er overfylt av varer, når de vanlige behov forlengst er imøtekommet? Svaret ligger i kunnskapsøkonomien. Kjente varer må utvikles videre, nye varer må oppfinnes, og forbrukerne må overbevises om at de har behov for det nye. Her er det ikke lenger nok med fysisk arbeidskraft. Hjernekraften må mobiliseres. Menneskets egne ressurser må utnyttes bedre hvis vi skal delta i konkurransen på det nye, febrilske, globale marked. Det gjelder ikke bare å bygge opp ny kunnskap. Økonomien har også bruk for vår evne til kreativitet, fleksibilitet, loyalitet, vårt personlige engasjement. Sådan blir mennesket selv den viktigste produksjonsfaktor.

Det som skjer i denne prosessen, synes å være intet mindre enn et paradigmeskift. Det er fare for at skolens pedagogiske diskurs, med dens humanistiske grunnlagstenkning, gradvis blir skiftet ut med den humankapitalistiske diskurs, med økonomiens og markedets rasjonalitet. Hensynet til materielle verdier kommer i forgrunnen, hensynet til ikkematerielle verdier blir trengt i bakgrunnen.

Vi ser klare tegn på at Finansministeriet styrer Undervisningsministeriet, at utdannelse defineres som 'investering'. Vi ser at politikkens verdibaserte selvstendighet forfaller, og staten går i tjeneste for markedet, som er blitt samfunnets hovedarena. I dette mønstret blir borgeren/mennesket redusert til arbeidskraft, bruker eller forbruker. Eller som den engelske økonom Angell uttrykker det: "Skolens opgave er at producere de rigtige mennesker med den rigtige viden og erfaring, så de kan virke som råstof for globale virksomheder." (Sitert etter Korsgaards Kundskabskaplobet.)

Selvsagt må utdannelsen kunne styrke både arbeidslivet og andre sider av livet. Det har den alltid gjort. Utdannelsen kan godt være med som produksjonsfaktor. Men den må være mer enn det! Det nye og konfliktskapende skjer når markedstenkningen erobrer utdannelsen. Da blir det tale om forskjellig grunnlagstenkning og menneskesyn. I $\varnothing$ konomiens optikk er ikke mennesket lenger et mål i seg selv. Det blir redusert til middel for den $\varnothing$ konomiske vekst. De pedagogiske begreper blir løsrevet fra sin verdibaserte kontekst og innført i en annen 
forståelsesramme, i en kontekst som kun opererer med materielle verdier. Innenfor denne trange rammen er det bare den kunnskap som kan måles og som kan frembringe salgsbare varer som teller. Verken 'dannelse', 'livsopplysning' eller 'folkeopplysning' er med i økonomiens ordbok.

Et sentralt punkt i Henrik Kaare Nielsens artikkel (i Demokrati og livslang laering) er at det globale markeds krav om utdannelse som produksjonsfaktor underminerer dansk tradisjon for myndiggjøring av den enkelte i et demokratisk fellesskap. 